\title{
Isolation and Screening of Lactobacillus bacteria for Ability to Produce Antibiotics
}

\author{
Chandra Mouli Lalam $^{1, *}$, P. Y. Naidu ${ }^{2}$, T. Srinivasan ${ }^{1}$ \\ ${ }^{1}$ Department of Biotechnology, GITAM Institute of Science, GITAM University \\ Visakhapatnam - 530045, India \\ ${ }^{2}$ Analytical research and development, Hospira, Chennai, India \\ *E-mail address: chandramoulilalam@gmail.com
}

\begin{abstract}
Antibiotic is one of the important commercially exploited secondary metabolites produced by bacteria and used in a wide range. Most of the antibiotics used today are isolated from the microbes. Bacteria are easy to culture, isolate, maintain and to improve their strain. Isolation of lactic acid bacteria (LAB) from soil, yoghurt and cheese was carried out. LAB were cultivated on De Man Rogosa Sharpe (MRS) agar and were characterized based on colony morphology, cell shape and biochemical tests. Out of eight samples analyzed, 96 isolates were identified as LAB. The bacterial isolates were identified as Lactococcus Lactis, Lactobacillus Brevis, Lactobacillus casei, Pediococcus damnosus, Lactobaciilus rhamnosus, Lactobacillus Plantarum, Lactobacillus pentosus, Enterococcus feacalis, Staphylococcus Simulans. Using MRS broth, the isolated LAB were screened for production of bacteriocins. Further, $96 \mathrm{LAB}$ screened for bacteriocin production, $12 \mathrm{LAB}$ were identified as bacteriocin producers. Out of 12 LAB, Enterococcus faecium (CST-1) was identified as potential bacteriocin producer against Bacillus subtlis MTCC-10403 Pseudomonas aureginosa MTCC-4676 microorganisms used while Pediococcus damnosus had the least bacteriocin activity against Staphylococcus aureus and Bacillus subtilis.
\end{abstract}

Keywords: Pseudomonas aureginosa; Pediococcus damnosus; bacteriocin activity; Staphylococcus aureus; Bacillus subtilis

\section{INTRODUCTION}

The term Lactic Acid Bacteria (LAB) was gradually accepted in the beginning of the 20th century (Carol et. al., 2010). Lactic acid bacteria is having direct influence on the organoleptic, shelf-life and nutritional characteristics because of this phenamenon LAB has long history of application in fermented foods (Leroy F et.al., 2004). Lactic acid bacteria is generally gram positive, non sporulating, usally non motile ,catalase negative, non respiring cocci or rods, and fastidious organisms, $\mathrm{LAB}$ produce lactic acid as an end product through fermentation of carbohydrates. Lactic acid bacteria is generally classified based on morphology, range of sugar utilization and mode of glucose fermentation. Lactic acid bacteria consisting of different number of bacterial genera within the phylum Firmicutes.

The genera includes Lactobacillus, Leuconostoc, pediococcus, streptococcus, Enterococcus, Oenococcus, Lactococcus, Carnobacterium, Lactosphaera, Vagococcus, Melliococcus, Tetragenococcus and weissels are recognized as LAB (Stiles and Holzapfel, 1997; Holzapfel et al., 2001; Jay, 2000). 
Lactic acid bacteria lack the ability to synthesize cytochromes and poryphirins and therefore cannot generate ATP, they obtain ATP only through sugar fermentation since lactic acid bacteria does not use oxygen in their energy production. Lactic acid bacteria can be easily grown in aerobic and as well as anerobic conditions, they are protected by oxygen byproducts because they have peroxidases, they are also known as aerotolerant anerobes(Michaela et al., 2009). These bacteria are differentiated from the other micro organisms by the ability to convert hexoses to lactic acid.

Lactic acid bacteria can be generally divided into two groups based on the sugar fermentation pathways, those organisms which produce exclusively lactic acid as end product are termed as Homofermentative lactic acid bacteria, and organisms which produce acetic acid, ethanol, $\mathrm{CO}_{2}$ in addition to lactic acid are termed as Heterofermentative LAB. All members of Pediococcus, Lactococcus, Streptococcus, Vagococcus, along with some lactobacilli are homofermenters.

Carnobacterium, Oenococcus, Enterococcus, Lactosphaera, Weissells and Lecconostoc and some Lactobacilli come under heterofermenters. The heterofermentative LAB gain more importance in food industries by producing aromatic and flovaour components such as diactyl and acetaldehyde.

LAB is Generally Recognized as safe (GRAS) organisms, Lactic acid bacteria is generally used in the production of fermented foods because for their ability to produce desirable change in colour, texture,taste and flovour. These lactic acid bacteria are mostly known to inhibit food borne pathogens and food spoilage microorganisms by producing different antimicrobial substances such as bacteriocins, lactic acid, ethanol, acetic acid, hydrogen peroxide and co2 and several aromatic compounds, because of these charcacteristic features LAB generally utilized for enhancing the safety and extendind shelf-life of food products. Bacteriocins produced by $\mathrm{LAB}$ are nothing but extracellular bacterial proteins secreted by the cells. The Bacteriocins of LAB can be easily degraded by the human gastrointestinal proteases because of this important feature LAB generally gained importance in the recent years in food preservation (Cleveland etal., 2001).

In recent years the use of Lactic acid bacteria as "Probiotics" is gaining more importance since because mainly lactobacillus and bifidobacteria may have several therapeutic functions (Berg, 1996; Oberg et al., 1998).

The objective of the present study was to isolate lactic acid bacteria from different sources like soil, curd, cheese and to screen these isolates for production of antimicrobial compounds.

\section{MATERIALS AND METHODS}

API 50CHL identification kit was purchased from Biomerieux, USA. MRS HiVeg agar, MRS HiVeg broth was procured from Himedia, Mumbai. All other chemical used in the present study were of analytical grade and purchased from Himedia, Mumbai, India and Merck, Bangalore, India.

\section{1. Collection of samples}

A total number of eight samples were analyzed for isolation and screening of LAB. Out of eight samples, four were soil samples were collected with sterile spoons from milk waste dumping yard at Visakhapatnam, tirupati and hyderabad, India at a depth of $20 \mathrm{~cm}$ and saved into clean bags. Curd and cheese samples were collected from chennai local market, 
Tamilnadu and were brought to the laboratory under sterile conditions. One gram of each collected soil, curd and cheese sample was serially diluted upto $10^{-1}$ to $10^{-7}$ in $0.9 \% \mathrm{NaCl}$ solution and plated on MRS agar medium, incubated at $37^{\circ} \mathrm{C}$ for 24 hours.

\section{2. Isolation and identification of the isolates}

From each plate of MRS agar, colonies with different morphologies were picked up randomly and transferred into the tubes containing MRS broth and were incubated in aerobic conditions at $37^{\circ} \mathrm{C}$ for 24 hours. This procedure was repeated until purity of the culture was established on the basis of colony appearance and microscopic observations such as gram staining. Each of the isolates was first tested for catalase by placing a drop of $3 \%$ hydrogen peroxide solution on the cells. Immediate formation of bubbles indicated the presence of catalase in the cells. Only those isolates which were catalase- negative were Gram-stained, and only those which were Gram-positive were further identified by the API 50CHL identification kit (Biomerieux).

The biochemical tests performed were Simmon's Citrate Slant test, Indole test, Methyl Red (MR), Voges Proskauer (VP) and Oxidase tests. Identification of isolates obtained in pure culture was based on Gram staining, morphology, growth characteristics on selective and differential media such as MRS agar and biochemical test results recommended in the Bergey's Manual of Determinative Bacteriology.

\section{3. Biochemical characterization of the isolates}

\subsection{Carbohydrate utilization}

The isolated LAB was further identified by their fermentative ability of carbohydrates using API50CHL kit.

\section{3. 2. Sodium chloride $(\mathrm{NaCl})$ tolerance}

For determination of $\mathrm{NaCl}$ tolerance, all the isolates were grown in MRS broth supplemented with different concentrations of $\mathrm{NaCl}$ (1-9 \%). The broths were inoculated with $100 \mu \mathrm{l}$ overnight culture of the isolates and incubated anaerobically at $37{ }^{\circ} \mathrm{C}$ for 24 hour. After 24 hour incubation, growth was determined using a spectrophotometer, reading the optical density at $600 \mathrm{~nm}$.

\section{3. 3. Optimization of culture temperature}

For the determination of optimum culture temperature growth of the isolates, $100 \mu 1$ overnight culture of the isolates were inoculated into MRS broth with varying temperatures ranging from $20,25,30,35,40$ and $40{ }^{\circ} \mathrm{C}$. The inoculated broths were then incubated for 24 h. Growth of the bacterial isolates was measured using a spectrophotometer at $560 \mathrm{~nm}$.

\section{3. 4. Optimization of culture $\mathrm{pH}$}

For the determination of optimum culture $\mathrm{pH}$ growth of the isolates, $100 \mu 1$ overnight culture of the isolates were inoculated into MRS broth with varying $\mathrm{pH}$ ranging from 5.0, 5.5, $6.0,6.5,7.0,7.5,8.0,8.5$ and 9.0. The inoculated broths were then incubated for $24 \mathrm{~h}$ at 37 ${ }^{\circ} \mathrm{C}$. Growth of the bacterial isolates was measured using a spectrophotometer at $560 \mathrm{~nm}$. 


\section{3. 5. Antibacterial activity of the isolates}

Agar well diffusion method was used to determine the antimicrobial activities of the isolated Lactobacillus sp according to the method of Murray et al., 1995. Four different indicator microorganisms belonging to gram positive and gram negative groups such as Bacillus subtilis (MTCC), Staphylococcus aureus (MTCC-3160), Escherichia coli (MTCC1652), Pseudomonas aeruginosa (MTCC-4676) were used in this study as test pathogen.

\section{RESULTS}

\section{1. Growth and morphology}

A total of 96 isolates were identified as Lactobacillus species using MRS agar medium. The isolates were subjected to grow on selective MRS agar media and produced round shape, off-white to cream color, shiny colonies those were quite similar to the reference Lactobacillus spp. grown on MRS agar media (Figure 1A). Isolates when Gram stained, found rod shaped, short-medium chain and positive in Gram reaction those all are typical characteristics of Lactobacillus spp. (Figure 1B). The isolates were able to grow at $\mathrm{pH}$ between 5.0 and 7.0, but the optimum growth was observed at $\mathrm{pH}$ between 5.5 and 6.5 when grown in MRS broth at $37^{\circ} \mathrm{C}$.

\section{2. Biochemical characterization}

For biochemical characterization, catalase, oxidase, indole, MR, VP and citrate tests were conducted and found negative for all the isolates. Carbohydrate utilization test was performed by using API50CHL identification kit (Biomerieux) to investigate whether the isolates can ferment carbohydrates and the results were described in Table No.1.

\section{3. Determination of antimicrobial activity}

The crude extract of eight strains of lactic acid bacteria gave zones of inhibition on to the indicator organisms. The diameters of inhibition are included between $2 \mathrm{~mm}$ to $6 \mathrm{~mm}$. the biggest diameter of $6 \mathrm{~mm}$ was obtained with crude extract of CST-1 against Bacillus subtilis (Figure 2) and the smallest diameter of $1 \mathrm{~mm}$ was obtained with crude extract of CST-6 against E.coli. 


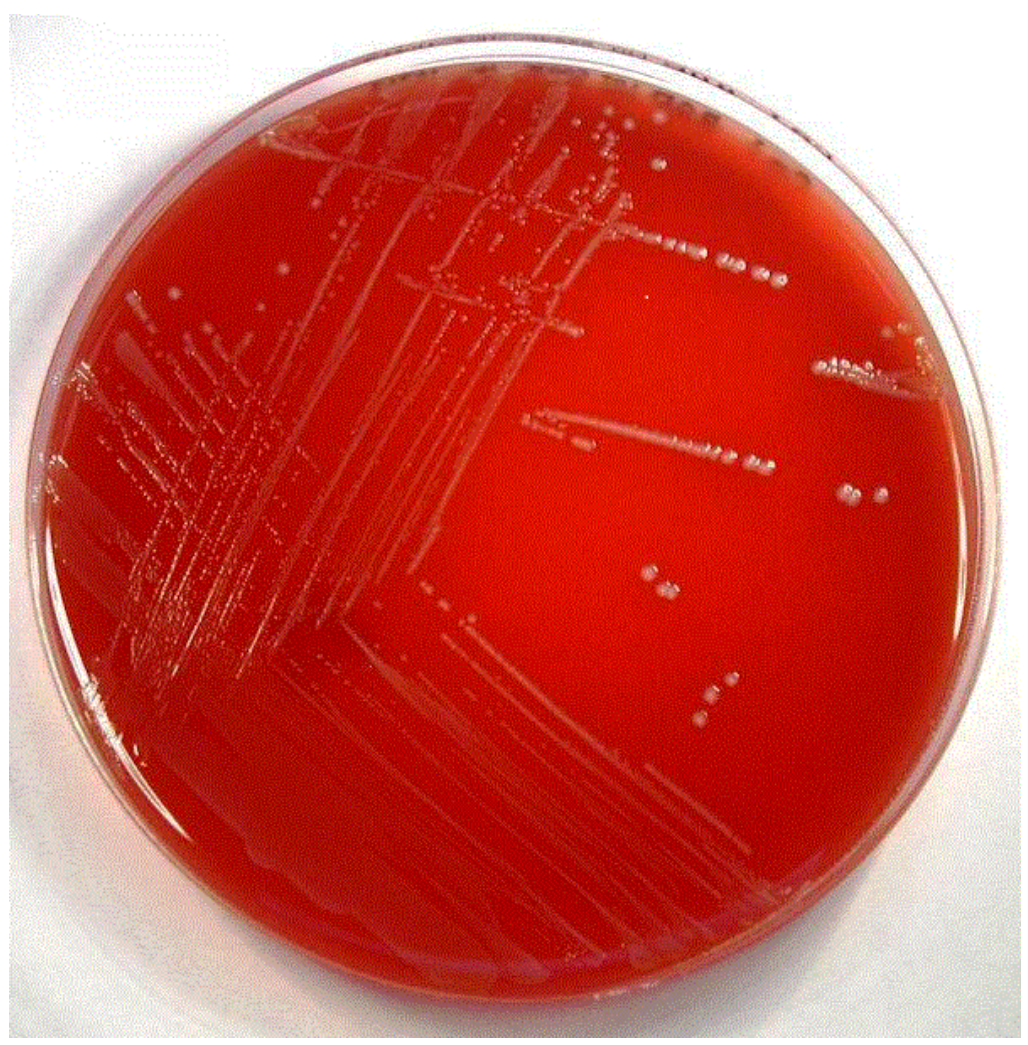

Figure 1. Strain CST-1 Enterococcus feacium on MRS agar.

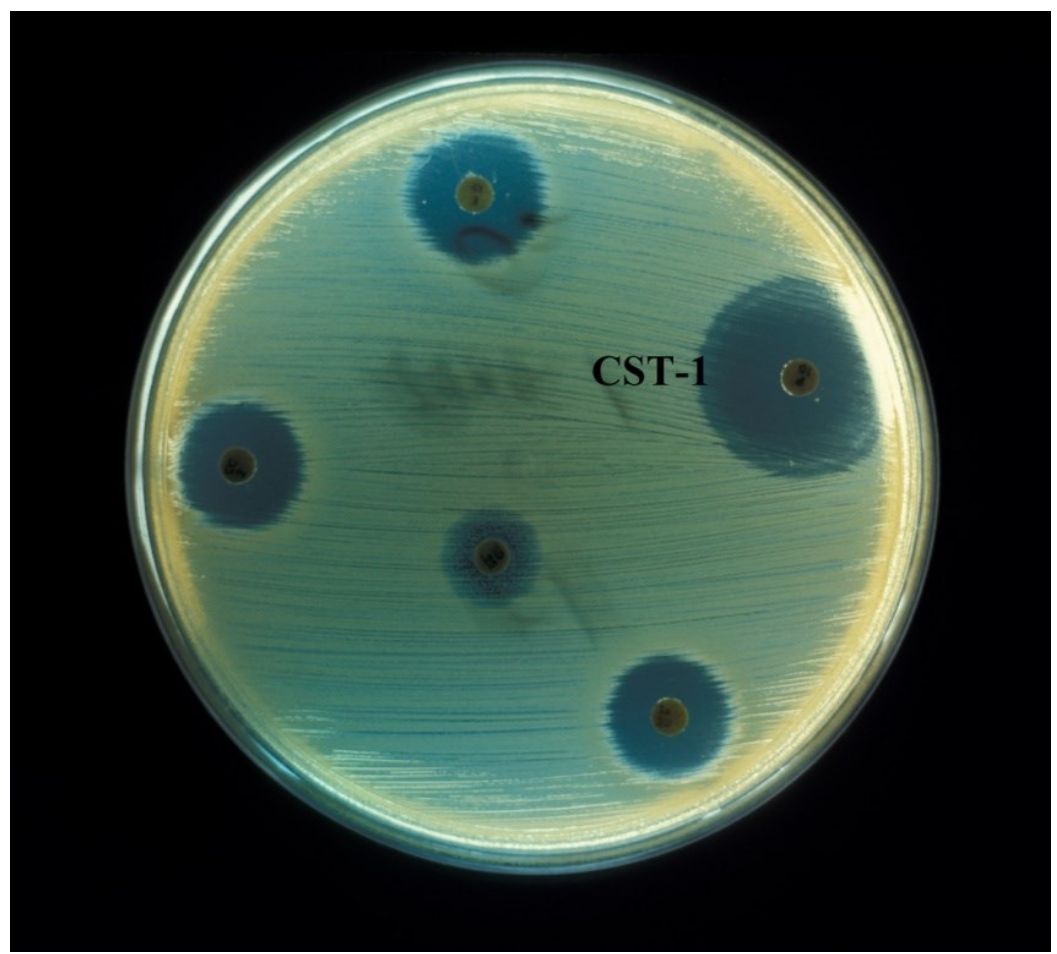

Figure 2. Well diffusion method for measuring the zone of inhibition. 


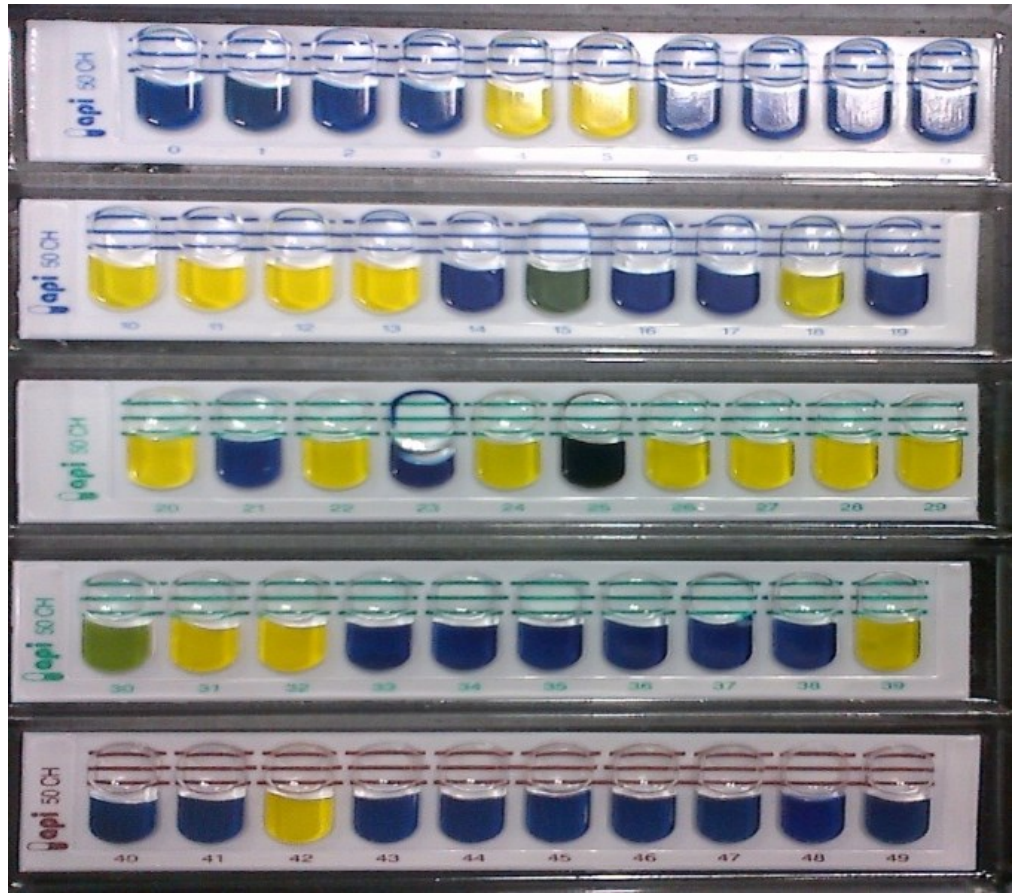

Figure 3. API 50 CHE strip analysis for strain CST-1. Yellow indicates positive.

Blue indicates negative.

Green indicates positive/negative.

Table 1. Isolation and the identification of isolates.

\begin{tabular}{|c|c|c|c|c|}
\hline $\begin{array}{c}\text { Strain } \\
\text { code }\end{array}$ & $\begin{array}{c}\text { Sampling } \\
\text { date }\end{array}$ & Source & Location & Species \\
\hline CST-1 & $15 / 10 / 2012$ & $\begin{array}{l}\text { soil from visakha } \\
\text { diary }\end{array}$ & visakhaptanam & Enterococcus faecium \\
\hline CST-2 & $02 / 11 / 2012$ & $\begin{array}{l}\text { soil from vijaya } \\
\text { diary }\end{array}$ & Tirupathi & $\begin{array}{l}\text { Lactobacillus. Brevis } \\
\text { Lactobacillus casei }\end{array}$ \\
\hline CST-3 & $03 / 11 / 2012$ & $\begin{array}{c}\text { soil from visakha } \\
\text { diary }\end{array}$ & visakhaptanam & $\begin{array}{l}\text { Pediococcus damnosus } \\
\text { Lactobaciilus rhamnosus }\end{array}$ \\
\hline CST-4 & $15 / 11 / 2012$ & curd sample & $\begin{array}{l}\text { Chennai local } \\
\text { market }\end{array}$ & Lactococcus lactis \\
\hline CST- 5 & $19 / 12 / 2012$ & $\begin{array}{l}\text { soil from tirumala } \\
\text { dairy }\end{array}$ & Hyderabad & $\begin{array}{c}\text { Lactobacillus } \\
\text { Plantarum, } \\
\text { Lactobacillus pentosus. }\end{array}$ \\
\hline CST-6 & $16 / 01 / 2013$ & cheese & $\begin{array}{l}\text { Chennai local } \\
\text { market }\end{array}$ & Enterococcus feacalis \\
\hline CST-7 & $21 / 01 / 2013$ & curd sample & $\begin{array}{c}\text { Chennai local } \\
\text { market }\end{array}$ & Staphylococcus Simulans \\
\hline CST-8 & $06 / 02 / 2013$ & cheese & $\begin{array}{l}\text { Chennai local } \\
\text { market }\end{array}$ & Enterococcus Feacalis \\
\hline
\end{tabular}


Table 2. Zone of Inhibition shown by isolated species on different test pathogens.

\begin{tabular}{|c|c|c|c|c|}
\hline Isolated colonies & $\begin{array}{c}\text { Bacillus subtilis } \\
\text { (MTCC-10403) }\end{array}$ & $\begin{array}{c}\text { Staphylococcus } \\
\text { aureus (MTCC- } \\
\mathbf{3 1 6 0 )}\end{array}$ & $\begin{array}{c}\text { Escherichia coli } \\
\text { (MTCC-1652) }\end{array}$ & $\begin{array}{c}\text { Pseudomonas } \\
\text { aeruginosa } \\
\text { (MTCC-4676) }\end{array}$ \\
\hline $\begin{array}{c}\text { Enterococcus } \\
\text { feacalis }\end{array}$ & $5.5 \mathrm{~mm}$ & $3.8 \mathrm{~mm}$ & $5.4 \mathrm{~mm}$ & $6.2 \mathrm{~mm}$ \\
\hline $\begin{array}{c}\text { Lactobacillus. } \\
\text { Brevis }\end{array}$ & $6.2 \pm 0.4 \mathrm{~mm}$ & $4.5 \mathrm{~mm}$ & $3.8 \mathrm{~mm}$ & $6.4 \mathrm{~mm}$ \\
\hline $\begin{array}{c}\text { Pediococcus } \\
\text { damnosus }\end{array}$ & $5 \pm 0.4 \mathrm{~mm}$ & $3.8 \mathrm{~mm}$ & $4.2 \mathrm{~mm}$ & $5.4 \mathrm{~mm}$ \\
\hline $\begin{array}{c}\text { Lactococcus } \\
\text { lactis }\end{array}$ & $5.8 \mathrm{~mm}$ & $4.2 \mathrm{~mm}$ & $5.4 \mathrm{~mm}$ & $9 \mathrm{~mm}$ \\
\hline $\begin{array}{c}\text { Lactobacillus } \\
\text { Plantarum. }\end{array}$ & $6.2 \pm 0.4 \mathrm{~mm}$ & $4.4 \mathrm{~mm}$ & $5.4 \mathrm{~mm}$ & $7.2 \mathrm{~mm}$ \\
\hline $\begin{array}{c}\text { Enterococcus } \\
\text { faecium CST-1 }\end{array}$ & $\mathbf{1 0 . 2 \pm \mathbf { 0 . 4 m m }}$ & $\mathbf{8 . 4} \mathbf{~ \mathbf { m m }}$ & $\mathbf{6 . 8 m m}$ & $\mathbf{8 . 6 \mathrm { mm }}$ \\
\hline $\begin{array}{c}\text { Lactobacillus } \\
\text { pentosus }\end{array}$ & $6.2 \pm 0.4 \mathrm{~mm}$ & $3.8 \mathrm{~mm}$ & $4.2 \mathrm{~mm}$ & $5.4 \mathrm{~mm}$ \\
\hline $\begin{array}{c}\text { Staphylococcus } \\
\text { Simulans }\end{array}$ & $3.8 \mathrm{~mm}$ & $4.2 \mathrm{~mm}$ & $5.4 \mathrm{~mm}$ & $10 \mathrm{~mm}$ \\
\hline $\begin{array}{c}\text { Lactobaciilus } \\
\text { rhamnosus }\end{array}$ & $4.4 \mathrm{~mm}$ & $3.6 \mathrm{~mm}$ & $4.2 \mathrm{~mm}$ & $5.4 \mathrm{~mm}$ \\
\hline $\begin{array}{c}\text { Lactobacillus } \\
\text { casei }\end{array}$ & $6.8 \mathrm{~mm}$ & $4.4 \mathrm{~mm}$ & $5.4 \mathrm{~mm}$ & $7.2 \mathrm{~mm}$ \\
\hline
\end{tabular}

Table 3. Biochemical characterization of isolated strains using API 50 CHE strip.

\begin{tabular}{|c|c|c|c|c|c|c|c|c|}
\hline ISOLATES & CST-1 & CST-2 & CST-3 & CST-4 & CST -5 & CST -6 & CST -7 & CST-8 \\
\hline Control & - & - & - & - & - & - & - & - \\
\hline Glycerol & - & - & - & - & - & - & - & - \\
\hline Erythritol & - & - & - & - & - & - & - & - \\
\hline D-Arabinose & - & - & - & - & - & - & - & - \\
\hline L-Arabinose & + & + & - & + & + & - & + & - \\
\hline D-Ribose & + & + & - & + & + & - & + & + \\
\hline D-xylose & + & + & - & - & - & + & + & - \\
\hline L-Xylose & - & - & - & - & - & - & - & - \\
\hline D-Adonitol & - & - & - & - & - & - & - & - \\
\hline $\begin{array}{c}\text { Methyl- } \beta \text { D- } \\
\text { xylopyranoside }\end{array}$ & - & - & - & - & - & - & - & - \\
\hline D-Galactose & + & + & - & + & + & + & + & + \\
\hline D-Glucose & + & + & + & + & + & + & + & + \\
\hline D-Fructose & + & + & + & + & + & + & $?$ & + \\
\hline D-Mannose & + & + & + & + & + & + & + & + \\
\hline L-Sorbose & - & - & - & - & - & - & - & - \\
\hline L-Rhamnose & - & - & - & $?$ & - & - & - & - \\
\hline Dulcitol & - & - & - & - & - & - & - & - \\
\hline Inositol & - & - & - & - & - & - & - & - \\
\hline D-Mannitol & - & + & - & + & + & + & - & + \\
\hline D-Sorbitol & - & - & - & - & + & + & + & - \\
\hline
\end{tabular}




\begin{tabular}{|c|c|c|c|c|c|c|c|c|}
\hline $\begin{array}{c}\text { Methyl- } \alpha \mathrm{D}- \\
\text { Mannopyranoside }\end{array}$ & + & - & - & + & + & - & + & + \\
\hline $\begin{array}{c}\text { Methyl- } \alpha \mathrm{D}- \\
\text { Glucopyranoside }\end{array}$ & - & - & - & - & + & - & - & - \\
\hline NAcetylglucosamine & + & + & + & + & + & + & + & + \\
\hline Amygdalin & + & + & - & - & + & - & $?$ & + \\
\hline Arbutin & + & + & - & + & + & + & + & - \\
\hline Esculinferric citrate & - & - & - & - & - & - & - & - \\
\hline Salicin & - & + & - & + & + & + & - & $?$ \\
\hline D-Cellobiose & + & + & - & + & + & - & & + \\
\hline D-Maltose & + & + & - & + & + & - & + & + \\
\hline $\begin{array}{l}\text { D-lactose(bovine } \\
\text { origin) }\end{array}$ & - & + & - & + & + & - & + & - \\
\hline D-Melibiose & - & + & - & $?$ & + & + & + & - \\
\hline D-Saccharose & + & + & - & + & + & - & + & + \\
\hline D-Trehalose & + & + & + & + & + & + & + & + \\
\hline Inulin & - & - & - & - & - & - & - & - \\
\hline D-Melezitose & - & - & - & - & + & - & - & - \\
\hline D-Raffinose & - & - & - & - & + & - & - & - \\
\hline Starch & - & - & - & - & - & - & - & - \\
\hline Glycogen & - & - & - & - & - & - & - & - \\
\hline Xylitol & - & - & - & - & - & - & - & - \\
\hline Genitobiose & - & - & - & + & + & - & + & + \\
\hline D-Turanose & - & + & - & - & - & - & $?$ & - \\
\hline D-Lyxose & - & - & - & - & - & - & - & - \\
\hline D-tagatose & + & + & - & + & - & + & - & + \\
\hline D-Fucose & - & - & - & - & - & - & - & - \\
\hline L-Fucose & - & - & - & - & - & - & - & - \\
\hline D-Arabitol & - & $?$ & - & - & - & $?$ & - & - \\
\hline L-Arabitol & - & - & - & - & - & - & - & - \\
\hline Potassium gluconate & - & + & - & - & - & - & $?$ & - \\
\hline $\begin{array}{c}\text { Potassium } \\
\text { 2-ketogluconate }\end{array}$ & - & - & - & - & - & - & - & - \\
\hline $\begin{array}{c}\text { Potassium } \\
5 \text { ketogluconate }\end{array}$ & - & - & - & - & - & - & - & $?$ \\
\hline
\end{tabular}

\section{DISCUSSIONS}

Antimicrobial activity is one of the most important selection criteria for probiotics. Antimicrobial effects of lactic acid bacteria are incurred by producing some substances such as organic acids (lactic, acetic, propionic acids), carbon dioxide, hydrogen peroxide, diacetyl, low molecular weight antimicrobial substances and bacteriocins. All the Lactobacillus isolates showed to inhibit the test organisms included in this study though they vary in zone of inhibition diameter. 


\section{CONCLUSION}

The cell-free supernatants from eight strains of lactic acid bacteria exhibited antimicrobial activity. Most of Lacto bacillus was grown in between $\mathrm{pH} 5.5$ and 6.5 at a temperature of $37^{\circ} \mathrm{C}$. The potential application of secondary metabolites as consumer friendly bio preservatives either the form of protective cultures are as additives is significant besides being less potentially toxic or carcinogenic than current antimicrobial agents, lactic acid bacteria and their byproducts have been shown to be more effective and flexible in several applications. The further studies will be focused on the optimization and characterization of these antibacterial compounds.

\section{Acknowledgement}

The authors are thankful to the management of GITAM University for providing necessary research facilities to carried out this work

\section{References}

[1] Carol AR, Leon MTD. 2010. Horizontal gene transfer amongst probiotic lactic acid bacteria and other intestinal microbiota: what are the possibilities? A review. Archives of Microbiology 193(3), 157-168.

[2] Leroy F, De Vuyst L: Lactic acid bacteria asfunctional starter cultures for the food fermentation industry. Trends Food Sci Technol 2004; 15: 67-78.

[3] Stiles, M.E., W.H. Holzapfel. 1997. Review article: Lactic acid bacteria of foods and their current taxonomy. Int. J. Food Microbiol. 36, 1-29

[4] Jay, J.M. 2000. Fermentation and fermented dairy products, pp. 113-130. In Modern Food Microbiology, 6th edition. An Aspen Publication, Aspen Publishers, Inc. Gaithersburg, USA.

[5] Holzapfel, W.H., P. Haberer, R. Geisen, J. Björkroth, U. Schillinger. 2001. Taxonomy and important features of probiotic microorganisms in food nutrition. Am. J. Clin. Nutr. $73,365 \mathrm{~S}-373 \mathrm{~S}$.

[6] Cleveland J,Montiville TJ, Nes I F \& Chikindas M L, Bacteriocins: Safe, natural antimicrobials for food preservation, Int. J Food Microbial, 71(2001)1-20.

[7] Michaela S, Reinhard W, Gerhard K,Christine M-E. 2009. Cultivation of anaerobic and facultatively anaerobic bacteria from spacecraft-associated clean rooms. Applied and Environmental Microbiology 11(75), 3484-3491.

[8] Berg, R., 1996. The indigenous gastrointestinal microflora. Trends Microbiol., 4: 430435 .

[9] Oberg, C.J., J.R. Broadbent and D.J. McMahon, 1998. Applications of EPS production by LAB. J. Appl. Microbiol., 150: 1187-1193. 